\title{
Spawner-isolated mortality virus from Australian Penaeus monodon
}

\author{
Carol A. Fraser, Leigh Owens* \\ Department of Biomedical and Tropical Veterinary Sciences, James Cook University of North Queensland, Townsville, \\ Queensland 4811, Australia
}

\begin{abstract}
In 1993, an epizootic occurred in captive Penaeus monodon spawners at a research facility in northern Queensland, Australia. The spawners exhibited lethargy, failure to feed, redness of the carapace and pleiopods, and an increased mortality rate. A reliable bioassay of $0.45 \mu \mathrm{m}$ filtered, cellfree extracts of infected tissue produced mortalities approaching $100 \%$ in inoculated prawns. On average, the infected prawns became dark red by Day 6, produced red faeces by Day 10 and first mortalities by Day 13. Red faeces was a feature of this disease that has not been previously reported. When the survival curves of a dietary route were compared to the inoculation route, there was a lag period of $21 \mathrm{~d}$. After subtraction of $21 \mathrm{~d}$, the survival curves were statistically the same $(G=1.284, \mathrm{df}=1, \mathrm{p}>0.05)$. Pathological changes were found in the subcuticular epithelium and underlying muscle, depleted haematopoletic tissue, lymphoidal organ, hepatopancreas and gut. Increased eosinophilic refractile matenal was observed in the subcuticular epithelium and basement membrane and in the capsule surrounding the hepatopancreas. There were extensive areas of haemocytic infiltration and melanisation of the subcuticular epithelium with haemocytic replacement and necrosis of the underlyng muscle. There were large areas of necrosis in the hepatopancreas, as cells with pyknotic nuclei sloughed into the lumen. Small ( $20 \mathrm{~nm}$ ) icosahedral virions were observed in gut cells with transmission electron microscopy, and partial characterisation indicated that it was a nonenveloped DNA virus, similar to a parvovirus.
\end{abstract}

KEY WORDS: Penaeus monodon $\cdot$ Spawner · Virus

\section{INTRODUCTION}

The intensification of prawn farming worldwide has been accompanied by the occurrence of disease which threatens the development of the industry. The major causes of disease have been identified as: opportunistic microorganisms which are part of the normal microflora of prawns in the wild (Chen 1992, Shariff \& Subasinghe 1992, Turnbull et al. 1994), inadequate control of the culture environment leading to stress which increases susceptibility to disease (Flegel et al. 1992, Liao et al. 1992), and pathogens introduced into susceptible populations, usually by importation of infected stock from different geographic areas (Lightner et al. 1983, Shariff \& Subasinghe 1992, Wyban 1992)

·E-mail: leigh.owens@jcu.edu.au
The use of wild-caught breeding stock can, through the movement of postlarvae, continuously introduce locally occurring pathogens into the farms (Lotz 1992, Wyban 1992). In April 1993, 300 wildcaught female spawners were held in experimental facilities in Townsville, Australia, to determine the effect of various photoperiods on maturation. In June 1993, the spawners started to die at an unprecedented rate, exhibiting symptoms of lethargy, failure to feed and redness of carapace and pleiopods ( $M$. Hall pers. comm.). Despite investigations, the cause of death was not immediately obvious and the mortality rate continued to climb until the experiment was prematurely terminated on 31 July 1993 (L. Trott pers. comm.). Infectivity studies indicated that an agent that passed through a $0.45 \mu \mathrm{m}$ membrane filter was involved and this paper describes those studies and the virus, named spawner-isolated mortality virus (SMV), that appeared to be involved. 


\section{MATERIALS AND METHODS}

Experimental animals. Giant tiger prawns Penaeus monodon ( 3 to $5 \mathrm{~g}$ or 8 to $10 \mathrm{~g}$ ) were caught by cast net in the grow-out ponds of Aquaculture Industries, Bluewater, Queensland, Australia. All tanks and equipment were disinfected for $24 \mathrm{~h}$ with a saturated solution of calcium hypochlorite, rinsed twice with tapwater, and filled with seawater. The $180 \mathrm{l}$ experimental tanks were equipped with 2 corner filters and 2 airstones, the $25 \mathrm{l}$ tanks with one of each of the above. The water temperature was maintained at 21 to $26^{\circ} \mathrm{C}$ and the salinity at 25 to $37 \mathrm{ppt}$. The filter wool was changed every second day and a $30 \%$ water change done weekly. During the water change, all filters were rinsed to remove debris. Uneaten food, moults, and faecal strings were removed from the tanks daily.

Inoculation study. The extract was prepared from $26 \mathrm{~g}$ of head muscle, gill and gut tissue from 6 frozen cephalothoraxes. The tissue was homogenised in $26 \mathrm{ml}$ of Dulbecco's Modified Eagle's Medium (DMEM, Trace Bioscience PL, cat. no. 50-013-PB) with 1\% calf serum, in stomacher bags. The homogenate was frozen. and stored overnight at $-20^{\circ} \mathrm{C}$. After thawing, the homogenate was clarified by centrifugation at $9000 \times g$ in an Eppendorf microfuge for $1.5 \mathrm{~min}$. Half of the extract was filtered through a $450 \mathrm{~nm}$ Sartorius Minisart filter using a $2.5 \mathrm{ml}$ Terumo disposable syringe, to form the cell-free extract. The other half was left as a crude extract.

Preliminary experiments involved 6 groups of 5 prawns each, inoculated with cell-free extract prepared as described above except that tissues were kept separate. Groups received extract from the gills, hepatopancreas, heart, muscle, ovaries and placebo, respectively.

Thirty healthy 3 to $5 \mathrm{~g}$ prawns were used for each of 3 treatments: negative controls inoculated with DMEM, prawns inoculated with cell-free extract, and prawns inoculated with crude extract. The prawns were inoculated with $50 \mu \mathrm{l}$ of extract by injection into the tail muscle using a $1 \mathrm{ml}$ Terumo syringe and a 25 gauge Neolus needle. After inoculation, each batch was maintained in a 180 l. glass aquarium for $30 \mathrm{~d}$ with dead and moribund prawns removed, dissected longitudinally and fixed in Davidson's fixative for histological examination. Deaths within $24 \mathrm{~h}$ postinoculation were attributed to the inoculation procedure. These prawns were not replaced.

Feeding study. Three groups of 30 healthy 8 to $10 \mathrm{~g}$ prawns were set up in $180 \mathrm{I}$ tanks as described previously. All prawns were starved for $1 \mathrm{~d}$ and those in the experimental tanks were fed, on 2 consecutive days, an equal weight of chopped prawns from the original epizootic or infected, chopped prawns from the inoculation experiment, whilst the controls were fed com- mercial pellets. The experiment was run for $50 \mathrm{~d}$ because this route of infection was expected to be slower.

Microscopy. Samples of tissue were processed by conventional histological techniques, stained with $\mathrm{H} \& \mathrm{E}$ and examined under bright light microscopy. Nerve tissue was stained with congo red to detect the presence of amyloid plaques, a screening test for prion infection.

For transmission electron microscopy (TEM), 5 moribund prawns were sedated in cold water, and the organs of interest quickly removed into petri dishes containing $2.5 \%$ gluteraldehyde in $0.1 \mathrm{M}$ cacodylate buffer at $\mathrm{pH} 7.1$. The tissues were cut into $1 \mathrm{~mm}$ cubes in the petri dishes, fixed for $30 \mathrm{~min}$ at room temperature $\left(24^{\circ} \mathrm{C}\right)$ and washed $2 \times 10 \mathrm{~min}$ in the $0.1 \mathrm{M}$ cacodylate buffer. The samples were stored in the cacodylate buffer at $4^{\circ} \mathrm{C}$. Before embedding, the samples were post-fixed in $1 \%$ osmium tetroxide in $0.1 \mathrm{M}$ cacodylate buffer for $1 \mathrm{~h}$ at $24^{\circ} \mathrm{C}$, and washed $2 \times 10 \mathrm{~min}$ with the same buffer. The post-fixed samples were dehydrated and embedded in Spurr's resin. The sections were stained with $2 \%$ uranyl acetate in $50 \%$ ethanol acidified with hydrochloric acid, for $7 \mathrm{~min}$, rinsed 4 times in distilled water and blotted dry. Then the sections were stained with lead acetate for $2 \mathrm{~min}$ and the rinsing steps repeated. Tissues of 3 prawns were examined with the TEM.

Isolation of the virus. Large ( 30 to $40 \mathrm{~g}$ ) prawns were inoculated with $100 \mu \mathrm{l}$ of the original cell-free extract and maintained for $14 \mathrm{~d}$, after which they were frozen at $-20^{\circ} \mathrm{C}$. The frozen head and gut tissues were homogenised in a Waring laboratory blender, 10 heads per $200 \mathrm{ml}$ of cold TNE (TN buffer, see below, $+1 \mathrm{mM}$ EDTA) buffer (Bonami et al. 1990), and the homogenates were kept on ice. The homogenate was frozen, thawed, ultrasonicated and step-clarified by centrifugation at $4^{\circ} \mathrm{C}$ at 6000,12000 and $28000 \times g$ in a Beckman J2-21 using a JA17 rotor for 10, 15 and $30 \mathrm{~min}$, respectively. Samples were taken at this step for the nucleic acid digestion study. The extract was concentrated from 450 to $6.5 \mathrm{ml}$ by ultracentrifugation at $240000 \times g$ for $3 \mathrm{~h}$ at $4^{\circ} \mathrm{C}$ in a Beckman L 7-55 ultracentrifuge, and resuspension of each pellet in a small volume of TN buffer $(20 \mathrm{mM}$ Tris- $\mathrm{HCl}, 400 \mathrm{mM} \mathrm{NaCl}$ at $\mathrm{pH}$ 7.5) (Bonami et al. 1990). To remove the melanin, 19 of activated charcoal (untreated powder 100 to 400 mesh) was added to the extract, which was then. stirred for $5 \mathrm{~min}$ at $4^{\circ} \mathrm{C}$, centrifuged at low speed $(3500 \times g)$ and the supernatant fluid retained. The extract was layered onto six 20 to $60 \%$ sucrose gradients and spun at $240000 \times g$ for $3 \mathrm{~h}$ at $4^{\circ} \mathrm{C}$. Six equal $(0.8 \mathrm{ml})$ fractions, from the bottom up, with the lowermost being designated fraction 1 , were collected and those containing virus were identified using inoculation of susceptible animals as a bioassay. Fractions 1, 2 and 3 (containing virus) from each tube were pooled 
across fractions, diluted $1 / 5$ to lower the sucrose concentration and ultracentrifuged to pellet the virus. Each pellet was resuspended in $100 \mu$ of TN buffer, then pooled, and examined for virions under TEM by negative staining. The remainder of the suspension was run on a 25 to $45 \%$ caesium chloride (CsCl) gradient at $210000 \times g$ for $16 \mathrm{~h}$ at $4^{\circ} \mathrm{C}$.

Characterisation of the virus. A sample of the stepcentrifuged, clarified homogenate retained from the isolation step was mixed 1:1 with chloroform at $4^{\circ} \mathrm{C}$ for 10 min. The extract was centrifuged at $6000 \times g$ for 5 min to separate the phases, and the aqueous layer was retained. Four prawns were inoculated with the treated extract and were maintained by the standard procedure in parallel to the nucleic acid digestion study.

The type of nucleic acid was determined by digestion within the intact virion either by DNase RQ1 (Promega) or RNase cocktail RNC-1 (Bresatec). The extract was dialysed overnight at $4^{\circ} \mathrm{C}$ in $10 \mathrm{mM}$ Tris$\mathrm{HCl}_{1} 2 \mathrm{mM} \mathrm{MgCl}_{2}$ at $\mathrm{pH} 7.5$ for the DNA digest, $2 \times$ SSC (15 mM sodium citrate, $150 \mathrm{mM}$ sodium chloride) for the single-stranded (ss)RNA digest, and in $0.1 \times$ SSC for the double-stranded (ds)RNA digest (Hull 1985). The digests were set up as $10 \mu$ DNase (2000 $\mathrm{k}$ units $\mathrm{ml}^{-1}$ ) in $1 \mathrm{ml}$ of extract, and 2 tubes with $5 \mu \mathrm{l}$ of RNase $\left(20 \mathrm{k}_{\text {units }} \mathrm{ml}^{-1}\right.$ ) into $1 \mathrm{ml}$ of extract, all in the appropriate buffers. The digestions were incubated for $3 \mathrm{~h}$ at room temperature and 4 prawns for each treatment were inoculated with $50 \mu$ l of extract. A sample of untreated extract was incubated with the digestions and used for inoculation of prawns for positive control. The negative control prawns were inoculated with $50 \mu$ l of TEN buffer.

Statistical analysis. The survival curves were plotted and the survival distributions were compared using the Wilcoxon (Gehan) test of SPSS Life Tables.

\section{RESULTS}

\section{Inoculated infectivity studies}

The prawns inoculated with the cell-free extract were very dark in colour by Day 8 (Table 1) and were producing red faeces. By Day 12 they exhibited lethargy, lack of co-ordination, and were falling onto their sides when resting on the bottom of the tank. Feeding had also decreased. On Day 14, some of the prawns were red, and 3 died. Prawns that were about to die rested on the cephalothorax rather than on their legs in a rostrum-down position. Prawns which had died overnight were found to have been partially cannibalised when inspected the following morning. The deaths continued until the experiment was terminated at Day 30 , when there was 1 surviving prawn.
Table 1. Penaeus monodon. Onset in days of colour changes, red faeces and first unequivocal mortalıty in experimental infections with spawner-isolated mortality virus. Standard deviation in brackets. Each row reports one experiment

\begin{tabular}{|c|c|c|c|}
\hline Treatment & Colour changes & Red faeces & Mortality \\
\hline \multirow[t]{14}{*}{ Inoculated } & 8 & 8 & 14 \\
\hline & \multirow[t]{3}{*}{14} & 15 & 15 \\
\hline & & 16 & 27 \\
\hline & & 8 & 8 \\
\hline & 11 & 17 & 17 \\
\hline & 4 & 15 & 28 \\
\hline & 6 & 7 & 10 \\
\hline & \multirow[t]{3}{*}{7} & 11 & 13 \\
\hline & & 12 & 13 \\
\hline & & 12 & 12 \\
\hline & 2 & 2 & 6 \\
\hline & \multirow[t]{3}{*}{4} & 9 & 14 \\
\hline & & 2 & 3 \\
\hline & & 2 & 2 \\
\hline Mean inoculated & $7( \pm 4.0)$ & $9.7( \pm 5.2)$ & $13( \pm 7.6)$ \\
\hline \multirow[t]{2}{*}{ Via ingestion } & 9 & 24 & 31 \\
\hline & 7 & 12 & 14 \\
\hline Mean via ingestion & n $8( \pm 1.4)$ & $18( \pm 8.5)$ & $23( \pm 12.0)$ \\
\hline
\end{tabular}

The prawns inoculated with the crude extract exhibited loss of appetite on Day 14 and some of the prawns were red and others were dark grey. On Day 15, they were producing red faeces and 2 died, which seemed to signal the onset of the epizootic, even though some early mortalities had occurred (Day 1 and Day 5). The deaths continued until the termination of the experiment on Day 30, when there was 1 surviving prawn (Table 2). The control prawns remained healthy and all survived to Day 30

None of the infected animals had food in the gut. Pathological lesions were observed in many organs of the infected prawns. Haemocytic infiltration was observed in the gut, and rounded cells and cellular debris were sloughed into the lumen. There were

Table 2. Penaeus monodon. Effect of various prawn extracts on experimental prawns

\begin{tabular}{|lcr|}
\hline Treatment & Gross symptoms & Mortalities \\
\hline Inoculation control & None & $0 / 30$ at $30 \mathrm{~d}$ \\
Cell-free extract & All & $29 / 30$ at $30 \mathrm{~d}$ \\
Crude extract & All & $29 / 30$ at $30 \mathrm{~d}$ \\
Pellet-fed & None & $9 / 30$ at $50 \mathrm{~d}$ \\
Spawner-fed & All & $23 / 30$ at $50 \mathrm{~d}$ \\
Experimental carcass-fed & All & $25 / 30$ at $50 \mathrm{~d}$ \\
Chloroform & All & $4 / 4$ at $30 \mathrm{~d}$ \\
DNase & None & $1 / 4$ at $30 \mathrm{~d}$ \\
ssRNase & All & $4 / 4$ at $30 \mathrm{~d}$ \\
dsRNase & All & $4 / 4$ at $30 \mathrm{~d}$ \\
Cell-free extract & All & $4 / 4$ at $30 \mathrm{~d}$ \\
(positive control) & & $1 / 4$ at $30 \mathrm{~d}$ \\
DMEM (negative control) & None & \\
\hline
\end{tabular}




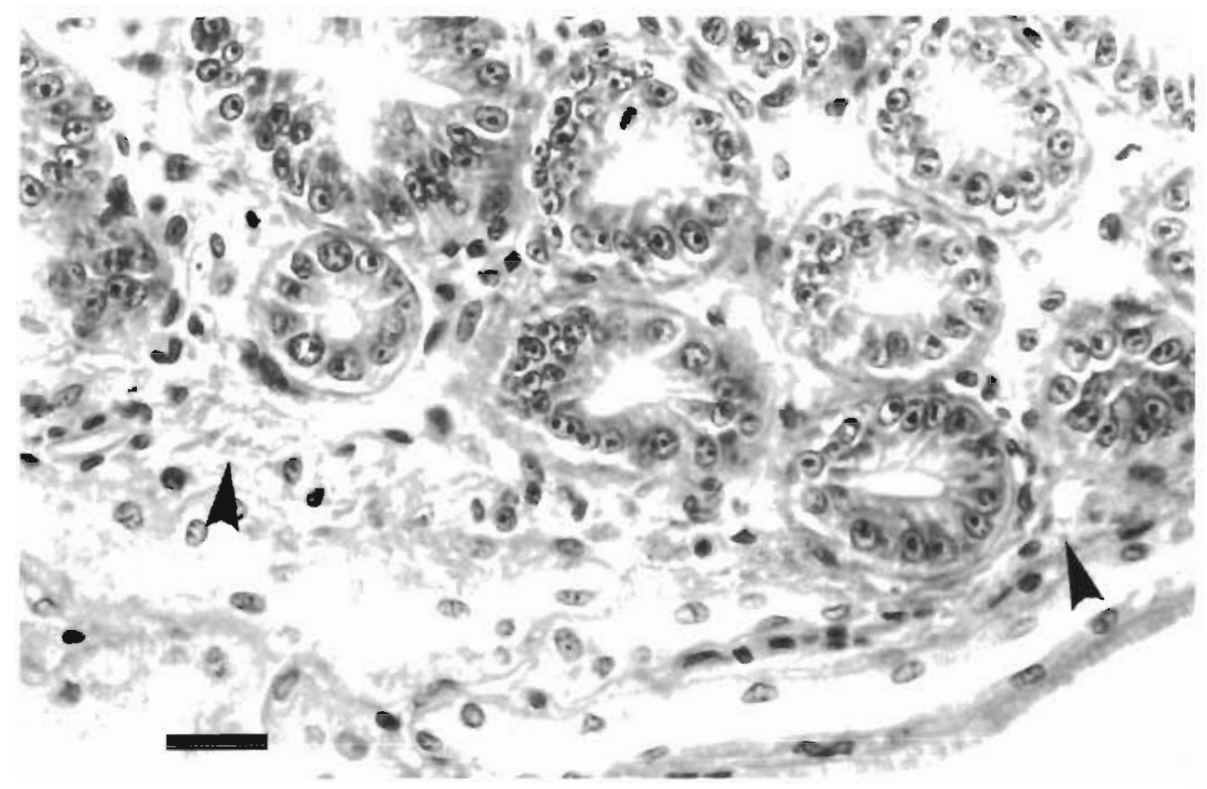

Fig. 1. Penaeus monodon. Hepatopancreas of spawner-isolated mortality virus (SMV)-infected prawns showing weak refractile eosinophilic granular material (arrowheads) in the connective tissue. Note also the larger than normal haemal sinuses and ab. normal basement membranes. Scale bar $=15 \mu \mathrm{m}$

marked changes in the hepatopancreas, with a marked increase in refractile eosinophilic granular material (REGM) in the capsule of the organ (Fig. 1), haemocytic infiltration around the tubules, pyknotic nuclei, cells sloughed into the lumen, and large areas of necrosis. Some prawns showed reduced numbers of hepatopancreatic tubules with increased haemal spaces between them. The hepatopancreatic tubules were shrunken so that the basement membrane of each tubule was crenulated with the circular muscle bands obvious. These haemal sinuses were larger as the tubules were no longer in contact with each other (Fig. 1). The haematopoietic tissue was depleted in some prawns, and the cytoplasmic 'blebbing' of haemocytic stem cells observed by O'Neill (1994) was present. The subcuticular epidermis, especially the basement membrane, displayed increased REGM (Fig. 2), extensive areas of haemocytic infiltration and melanisation, with haemocytic replacement and necrosis of the underlying muscle. The eyestalk had heavy REGM deposition. The lymphoidal organ displayed changes such as spheroids. The control prawns did not exhibit any of these abnormalities.

Histochemical staining was performed in an effort to determine the nature of REGM. The REGM looks like haemoglobin in mammalian tissues. It stained positive
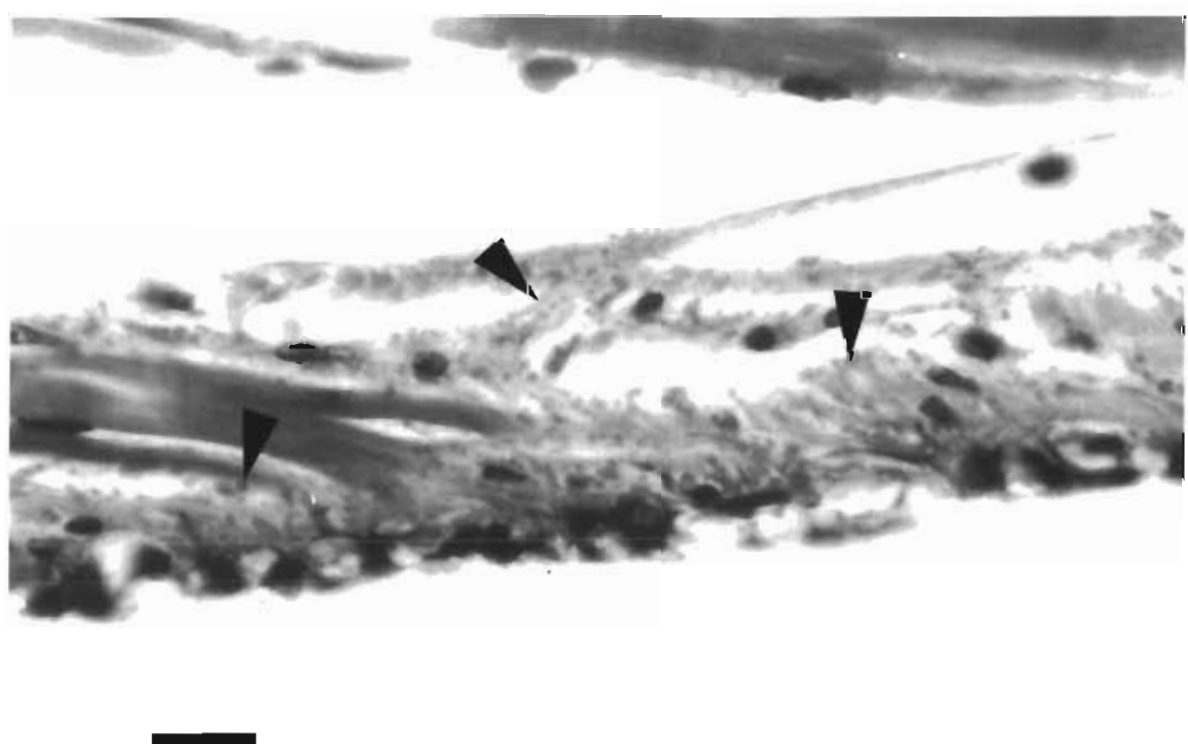

Fig. 2. Penaeus monodon. Cuticular hypodermal tissue with widespread refractile eosinophilic granular material (including the arrowheads) throughout the connective tissue layer. Scale bar $=15 \mu \mathrm{m}$ 
for haemoglobin and phloxine (phloxine-tartrazine) but negative for all of the following, ferrous (Turnbull's stain) and ferric ions (Perl's Prussian Blue stain), copper (Rubeanic acid stain) and lipofuscin (Schmorl's reagent). Amyloid plagues were not detected, under polarised light, in sections of nerve tissue stained with Congo red (Bendheim et al. 1984).

\section{Feeding studies}

Some of the prawns fed prawn tissue from the epizootic were red/dark grey by Day 9, lethargic on Day 14, and produced red faeces on Day 24. Feeding decreased on Day 19 and the first prawn died on Day 31. The deaths continued until Day 50, when there were 7 surviving prawns (Tables $1 \& 2$ ).

The prawns fed the experimentally infected tissue turned red/dark grey on Day 7. They produced red faeces on Day 12, were lethargic on Day 14 and decreased feeding on Day 19. The first prawn died on Day 14, but the next death did not occur until Day 30 , after which the deaths continued until Day 50, when there were 5 surviving prawns (Table 2).

The control prawns remained healthy except for 8 prawns which died between Days 41 and 47 . These prawns did not have any of the gross symptoms of the infected prawns, and the deaths could not be linked to moulting. There were no further deaths after Day 47 , when there were 21 surviving prawns (Table 2).

The pathological changes occurred in the same organs as in those prawns from the inoculation experiment. There were no inclusion bodies evident in any cells. Rounded cells were sloughed into the lumen of the gut and the underlying muscle was almost liquefied. The hepatopancreas displayed heavy haemocytic infiltration in the haemal sinuses between the tubules, and many cells with pyknotic nuclei were evident in large areas of necrotic tissue. The haematopoietic tissue was depleted with few mitotic cells evident. There were massive subcutaneous lesions with haemocytic infiltration and necrosis of the epidermis and the underlying muscle. Heavy melanisation was evident under the intact cuticle and irregular haemocytes were present. REGM was again present in hypodermal tissues. The lymphoid organ spheroids were encapsulated by a layer of fibrocytes, and pyknotic nuclei were evident.

The controls which died and 3 healthy controls were also examined under light microscopy, but no lesions were evident and the cause of death on Days 41 to 47 was not determined.

\section{Electron microscopy}

Sections of gut, hepatopancreas, gills, nerve and muscle were examined under transmission electron microscopy. Aggregations of virus-like particles were observed in the cytoplasm of the gut cells (Figs. $3 \& 4$ ). Under higher magnification $(\times 50000)$, the virions, which were approximately $20 \mathrm{~nm}$ in diameter, were hexagonally shaped suggesting icosahedral symmetry and appeared to be issuing from the nucleus through pores in the nuclear membrane. The virions were not detected in the other tissue sections. Two of 3 prawns examined showed these particles. We have named the virus spawner-isolated mortality virus (SMV).

There was some longer filamentous material of unknown nature (upper right Fig. 3 and lower left Fig. 4) associated with the virion-like particles. This material cannot be collagen nor its precursors. It is not extracellular, ruling out collagen, and it is approximately 20 to $30 \mathrm{~nm}$ in width, ruling out the possibility that it is tropocollagen, which is only $1.5 \mathrm{~nm}$ wide (Stryer 1988). Possibly, it is uncut nucleic acid awaiting virion packaging or it is nucleic acid of another associated virus.

The $\mathrm{CsCl}$ gradients were highly contaminated by melanin and so no band due to the virus was seen. Similarly, negatively stained preparations for the TEM failed to demonstrate virions, again due to melanin problems.

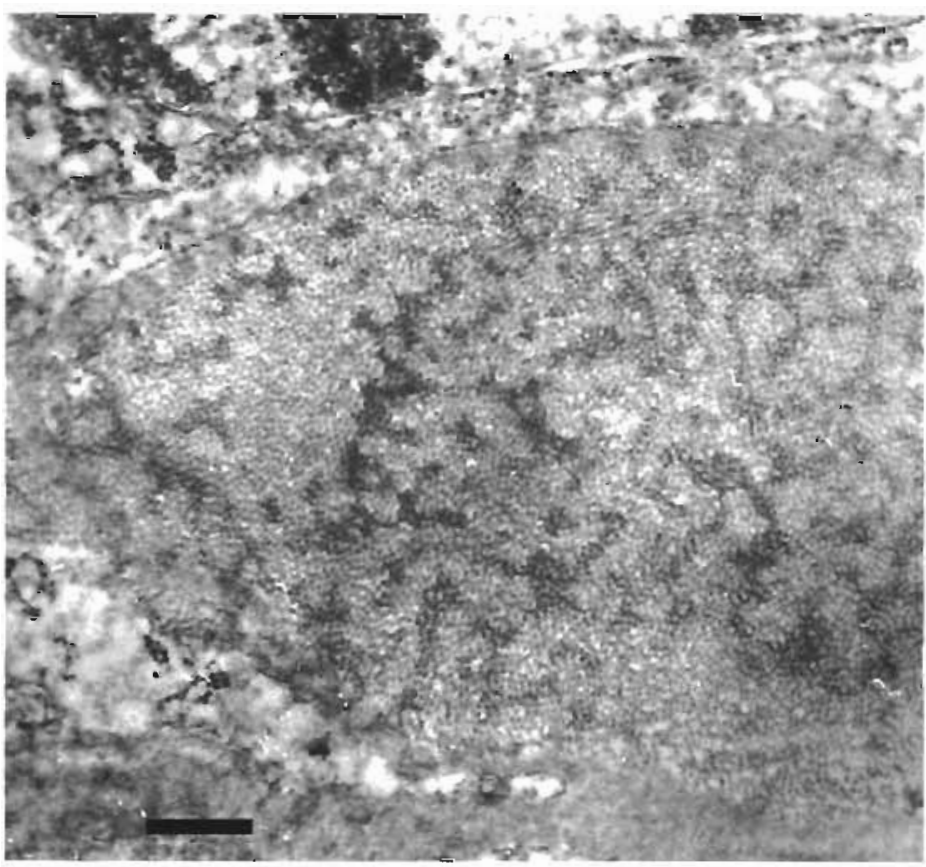

Fig. 3. Penaeus monodon. Electron micrograph of connective tissue layer of the midgut of SMV-infected prawns. Massive arrays of virionlike particles are present. Scale bar $=\mathrm{ca} 400 \mathrm{~nm}$ 


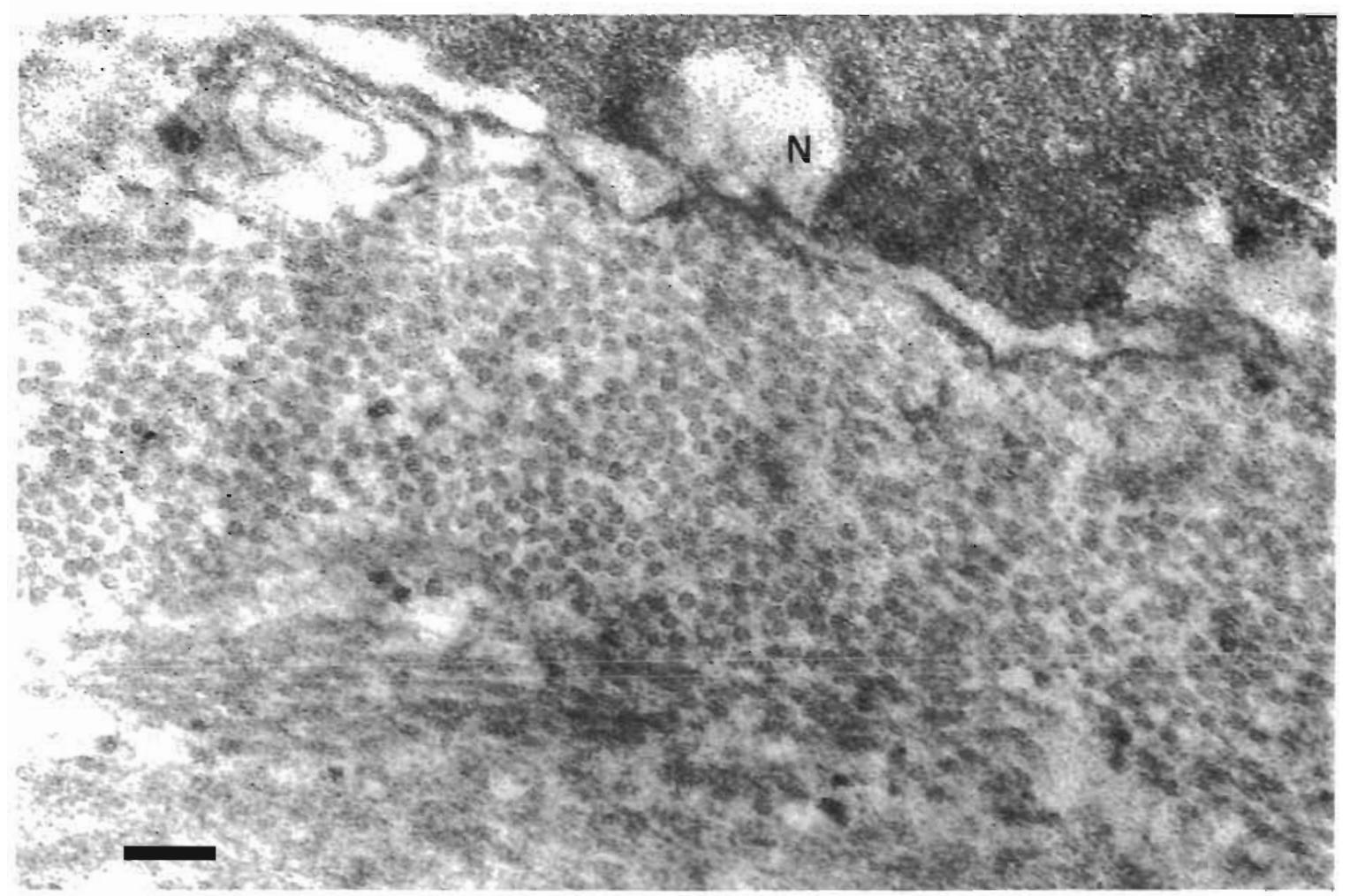

Fig. 4. Penaeus monodon. Electron micrograph of virion-like array in the midgut cells from SMV-infected prawns. Virion-like particles are approximately $20 \mathrm{~nm} . \mathrm{N}=$ nucleus. Scale bar $=100 \mathrm{~nm}$

\section{Survival curves}

The survival curves in the inoculation study (Fig. 5) showed a very close correlation $(G=3.042$, $\mathrm{df}=1$, $\mathrm{p}>0.05$ ) between the 2 batches which had been inoculated with the prawn extracts, but no statistical similarity between the infected batches and the con-

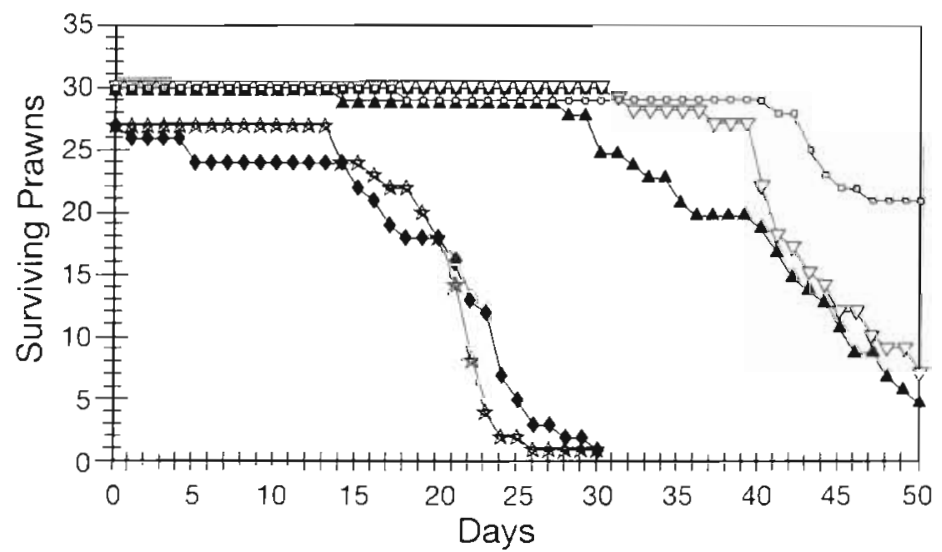

- Feeding Control $\rightarrow$ Spawner-fed $\quad-$ Exper. Carcass-fed

- Inoculation Control - Cell-free Extract $\rightarrow$ Crude Extract

Fig. 5. Penaeus monodon. Survival curves of prawns experimentally infected with SMV prawn extracts via inoculation and ingestion trol batch (Table 3). The survival curves in the feeding experiment (Fig. 5) similarly showed very close correlation between the 2 treatments which had been fed the diseased prawns $(G=0.809$, df $=1, \mathrm{p}>$ $0.05)$, but no similarity between the infected batches and the control batch (Table 3). When the survival curves of the dietary route were compared to the inoculation study, there appeared to be a lag period of $21 \mathrm{~d}$ before the major die-offs occurred. After an adjustment was made for this lag period by taking away the first $21 \mathrm{~d}$ from the feeding trials, the survival curves of the infected batches from both the inoculated and feeding studies were statistically identical, regardless of the mode of infection (Table 3).

\section{Isolation and characterisation of the virus}

Prawns inoculated with chloroform-treated material produced red faeces by Day 2 and 2 prawns were red. The first prawn died on Day 6. Another prawn which was dark grey and lying on its side on Day 8 died on Day 10. All the prawns were dead by Day 30 (Table 2) 
Table 3. Pendeus monodon. Statistical analysis of survival curves (Gehan statistic, $G_{i}$ df for all comparisons is 1). All feeding experiments have had the initial $21 \mathrm{~d}$ deducted to align survival curves

\begin{tabular}{|c|c|c|}
\hline Paired comparisons & $G$ & $\mathrm{p}$ \\
\hline $\begin{array}{l}\text { Inoculation control - } \\
\text { Cell-free filtrate }\end{array}$ & 43.74 & $<0.001$ \\
\hline $\begin{array}{l}\text { Inoculation control - } \\
\text { Crude extract }\end{array}$ & 40.35 & $<0.001$ \\
\hline $\begin{array}{l}\text { Cell-free filtrate - } \\
\text { Crude extract }\end{array}$ & 3.04 & $>0.05$ \\
\hline $\begin{array}{l}\text { Pellet-fed control- } \\
\text { Spawner-fed }\end{array}$ & 14.92 & $<0.001$ \\
\hline $\begin{array}{l}\text { Pellet-fed control - } \\
\text { Experimental carcass-fed }\end{array}$ & 17.78 & $<0.001$ \\
\hline $\begin{array}{l}\text { Spawner-fed - } \\
\text { Experimental carcass-fed }\end{array}$ & 0.81 & $>0.05$ \\
\hline $\begin{array}{l}\text { Spawner-fed - } \\
\text { Cell-free filtrate }\end{array}$ & 1.28 & $>0.05$ \\
\hline $\begin{array}{l}\text { Spawner-fed- } \\
\text { Crude extract }\end{array}$ & 0.01 & $>0.05$ \\
\hline $\begin{array}{l}\text { Experimental carcass-fed - } \\
\text { Cell-free filtrate }\end{array}$ & 0.06 & $>0.05$ \\
\hline $\begin{array}{l}\text { Experimental carcass-fed - } \\
\text { Crude extract }\end{array}$ & 0.79 & $>0.05$ \\
\hline
\end{tabular}

Prawns inoculated with DNAase-treated material appeared healthy and continued to feed. One prawn died at Day 17 but had no symptoms of the disease. The 3 survivors were active and feeding at Day 30 .

One of the prawns inoculated with the extract treated by ssRNA digestion, was red on Day 4. Red faeces was produced by Day 9 , when 3 of the prawns were dark and reddish. The first mortality was on Day 14 and there were no survivors at Day 30.

Two of the prawns inoculated with extract treated for dsRNA digestion were red and produced red faeces by Day 2. The first prawn died at Day 3. All prawns were dark and reddish by Day 9 and were not feeding. There were no survivors at Day 30 (Table 2).

The prawns inoculated with extract from the previously infected prawns (positive controls) produced red faeces by Day 2, and 2 dark prawns died. By Day 3 , the surviving prawns were red and not feeding. There were no survivors at Day 30.

The prawns inoculated with DMEM (negative controls) remained healthy and continued to feed. One prawn which had been partly cannibalised was found dead on Day 5. As a recent moult was floating in the water and the prawn had not shown any abnormal symptoms, this death was unlikely to be related to disease. Three prawns survived at Day 30.

\section{DISCUSSION}

The appearance of red faeces was first noted in preliminary studies and, as it has not been reported in other diseases, may be of major importance in initial diagnosis of the disease. The production of red faeces occurred consistently in infected prawns before the onset of mortalities (Table 1) and was easily detected in aquaria. However, detection of red faeces could be difficult in tanks or growout ponds. The other gross signs were non-specific but the survival of the controls indicated that they were caused by an agent in the extracts. The signs of the disease were reproduced by inoculation of healthy prawns, with a cell-free extract of homogenised tissue of prawns which had died in the original epizootic, satisfying Rivers' postulate (Rivers 1937).

The lack of pathognomic lesions or inclusion bodies hampered this disease investigation. Many of the histopathological changes would be considered nonspecific and easily confused with bacteraemic prawns. The deposition of REGM, which is the most useful characteristic, may itself be a natural phenomena which is accelerated by the viral attack. The lack of lesions is hard to comprehend for the severity of the disease but it is probably occurring at a subtle level, masked to the observer. This lack of lesions sets SMV apart from all the other known viruses of prawns, all of which have identifiable gross signs (Chantanachookhin et al. 1993), inclusion bodies (Lightner 1985) or lesions.

Although prions have only been found to cause disease in mammals (Prusiner 1987), nerve sections were stained with Congo red in order to eliminate prions as the other possible non-filterable infectious agents. Stained amyloid plaques of prion protein show green birefringence under polarised light (Bendheim et al. 1984), but these were not evident. upon careful examination of the prawn nerve tissue studied here.

The differences in the time of onset of symptoms and mortality between the inoculation study and the feeding study could be confounded by the slightly larger prawns used in the feeding study ( 8 to $10 \mathrm{~g}$ ) over the inoculation study ( 3 to $5 \mathrm{~g}$ ). Only by further research can the possible size effect be addressed.

Although the nucleic acid digestion was carried out with intact virions, the survival of prawns inoculated with DNase-treated extracts and the mortality with the RNase-treated extracts strongly suggested that the virus involved had a DNA genome. The infectivity of the chloroform-treated extract suggests that the virus is nonenveloped. This supported TEM observations that the virus-like particles (Figs. 4 \& 5) showed no viral budding nor envelopes. 
The small size (ca $20 \mathrm{~nm}$ ), shape and close association with the nucleus is very similar to the morphology of Australian infectious hypodermal and haematopoietic necrosis virus (IHHNV) discovered by Owens et al. (1992) and the original IHHNV described by Lightner \& Redman (1981), suggesting that SMS virus may be a parvovirus, but confirmation must await purification and characterisation of the nucleic acid.

\section{LITERATURE CITED}

Bendheim PE, Barry RA, DeArmond SJ, Stites DP, Prusiner SB (1984) Antibodies to a scrapie prion protein. Nature 310: $418-421$

Bonami JR, Trumper B, Mari J, Brehelin M, Lightner DV (1990) Purification and characterisation of the infectious hypodermal and haematopoietic necrosis virus of penaeid shrimps. J Gen Virol 71:2657-2664

Chantanachookhin C, Boonyaratpalin S, Kasornchandra J, Direkbusarakom S, Ekpanithanpong U, Supamataya K, Sriurairatana S, Flegal TW (1993) I listology and uitrastructure reveal a new granulosis-like virus in Penaeus monodon affected by yellow-head disease. Dis Aquat Org 17:145-157

Chen D (1992) An overview of the disease situation, diagnostic techniques, treatments and preventives used in shrimp farms in China. In: Funks W, Main KL (eds) Diseases of cultured penaeid shrimp in Asia and the United States of America. The Oceanic Institute Hawaii, Honolulu, p 47-55

Flegel TW, Fegan DF, Kongsom $S$, Vuthikmudomkit $S$, Sriurairatana S, Boonyaratpalin S, Chantanachookhin C, Vickers J, MacDonald OD (1992) Occurrence, diagmosis and treatment of shrimp diseases in Thailand. In: Funks W, Main KL (eds) Diseases of cultured penaeid shrimp in Asia and the United States of America. The Oceanic Institute Hawaii, Honolulu, p 58-112

Hull R (1985) Purification, biophysical and biochemical characterisation of viruses with especial reference to plant viruses. In: Mahy BMJ (ed) Virology-a practical approach. IRL Press, Washington DC, p 1-24

Liao IC, Su MS, Chang CF (1992) Diseases of Penaeus monodon in Taiwan: a review from 1977 to 1991. In: Funks W, Main KL (eds) Diseases of cultured penaeid shrimp in Asia and the United States of America. The Oceanic Institute Hawaii, Honolulu, p 113-137

Responsible Subject Editor: J. E. Stewart, Dartmouth, Nova Scotia, Canada
Lightner DV (1985) A review of the diseases of cultured penaeid shrimps and prawns with an emphasis on recent discoveries and developments. In: Taki Y, Primavera JH, Llobrera JA (eds) Proceedings of the first international conference on the culture of penaeid prawns/shrimps. Aquaculture Department of Southeast Asian Fisheries Department Philippines, Iloilo, p 79-103

Lightner DV, Redman RM (1981) A baculovirus-caused disease of the penaeid shrimp Penaeus monodon. J Invertebr Pathol 38:299-302

Lightner DV, Redman RM, Bell TA, Brock JA (1983) Detection of IHHN virus in Penaeus stylirostris and Penaeus vannamei imported into Hawaii. J World Maricult Soc 14: $212-225$

Lotz JM (1992) Developing specific pathogen-free (SPF) animal populations for aquaculture: a case study for IHHN virus of penaeid shrimp. In: Funks W, Main KL (eds) Diseases of cultured penaeid shrimp in Asia and the United States of America. The Oceanic Institute Hawaii, Honolulu, p 269-283

O'Neill AC (1994) Flow cytometry: a potential tool for assessing the health of the tiger prawn Penaeus monodon. BSc (Hons) thesis, Department of Biomedical and Tropical Veterinary Sciences, James Cook University of North Queensland

Owens L, Anderson IG, Kenway M, Trott L, Benzie JA (1992) Infectious hypodermal and haematopoietic necrosis virus (IHHNV) in a hybrid penaeid prawn from tropical Australia. Dis Aquat Org 14:219-228

Prusiner SB (1987) Prions and neurodegenerative diseases. New Engl J Med 317:1571-1581

Rivers TM (1937) Viruses and Koch's Postulates. J Bacteriol 33(1): $1-12$

Shariff M, Subasunghe RP (1992) Major diseases of cultured shrimp in Asia: an overview. In: Funks W, Main KL (eds) Diseases of cultured penaeid shrimp in Asia and the United States of America. The Oceanic Institute Hawaii. Honolulu, p 37-46

Stryer L (1988) Biochemistry, 3rd edn. Freeman and Co., New York

Turnbull JF, Larkins PE, MCPadden C, Matondang R (1994) A histopathological disease survey of cultured shrimp in North East Sumatra, Indonesia. J Fish Dis 17:57-65

Wyban JA (1992) Selective breeding of specific pathogen-free (SPF) shrimp for high health and increased growth. In: Funks W, Main KL (eds) Diseases of cultured penaeid shrimp in Asia and the United States of America. The Oceanıc Institute Hawaii, Honolulu, p 257-268

Manuscript first received: December 6, 1995

Revised version accepted: May 13, 1996 